\title{
Karakterisasi Karbamazepin Hasil Rekristalisasi Berbagai Pelarut Organik dengan Metode Slow Evaporation
}

\section{Characterization of Carbamazepine from Recrystallization of Various Organic Solvents Using Slow Evaporation Method}

Indra*, Rendi Rahman, Rika Yulianti

Program Studi Farmasi, Sekolah Tinggi Ilmu Kesehatan Bakti Tunas Husada, Tasikmalaya, Indonesia

*Corresponding author: indraf04@stikes-bth.ac.id

Submitted: 21 November 2020

Accepted: 16 June 2021

Published: 30 November 2021

\begin{abstract}
Background: Carbamazepine is a class II Biopharmaceutical Classification System (BCS), which means that carbamazepine has high membrane permeability and low solubility. Recrystallization is a way to modify crystals in an effort to change the physicochemical properties and dissolution rates of drugs. Objective: This study aims to evaluate the physicochemical properties of carbamazepine through the recrystallization of various solvents. Methods: This research carried out the recrystallization process of carbamazepine by evaporation of multiple solvents, namely ethanol, tetrahydrofuran (THF), and chloroform. The recrystallized solids were characterized using FTIR spectrophotometry, powder X-ray diffraction, and differential scanning calorimetry (DSC). Furthermore, the micromeritic evaluation and dissolution test was carried out. Results: The analysis results with FTIR and PXRD showed no change in the chemical structure of carbamazepine, but it caused changes in the internal structure and changes in the shape or called polymorphism of the carbamazepine crystals. Micromeritic evaluation showed a difference in the functional properties of the crystallized solids compared to pure carbamazepine, where the crystalline solids from ethanol recrystallization showed better micromeritic properties than the pure form. Carbamazepine crystals recrystallized using THF solvent have the highest dissolution rate than others, where at 60 minutes, the amount of dissolution is 65.09\%. Conclusion: The recrystallization of carbamazepine with ethanol, tetrahydrofuran, and chloroform results in new polymorphs. The physicochemical properties of recrystallized solids differ from those of pure carbamazepine. Carbamazepine powder recrystallized with tetrahydrofuran solvent has the highest dissolution rate compared to other solvents.
\end{abstract}

Keywords: carbamazepine, crystallization, solvent, solids characterization, slow evaporation

\begin{abstract}
Abstrak
Pendahuluan: Karbamazepin termasuk ke dalam golongan Biopharmaceutical Classification System (BCS) kelas II yang artinya bahwa karbamazepin memiliki permeabilitas membran tinggi dan kelarutan rendah. Rekristalisasi merupakan salah satu cara untuk memodifikasi kristal dalam upaya mengubah sifat fisikokimia dan laju disolusi obat. Tujuan: Penelitian ini bertujuan untuk mengevaluasi sifat fisikokimia karbamazepin melalui rekristalisasi berbagai pelarut. Metode: Pada penelitian ini dilakukan rekristalisasi dengan cara penguapan pelarut menggunakan pelarut etanol, tetrahidrofuran (THF), dan kloroform. Padatan kristal hasil rekristalisasi dikarakterisasi dengan menggunakan spektrofotometri FTIR, difraksi sinar-X (PXRD), dan analisis differential scanning calorimetry (DSC). Selanjutnya dilakukan evaluasi mikromeritik dan uji disolusi. Hasil: Berdasarkan hasil karakterisasi dengan FTIR dan PXRD menunjukan tidak terjadi perubahan struktur kimia dari karbamazepin, tetapi menyebabkan perubahan internal struktur dan perubahan bentuk (polimorfisme) kristal karbamazepin. Hasil evaluasi mikromeritik menunjukkan adanya perubahan sifat fungsional pada padatan kristal hasil rekristalisasi dibandingkan dengan karbamazepin murni, diketahui padatan kristal hasil rekristalisasi etanol menunjukkan sifat mikromeritik yang lebih baik dibandingkan bentuk murni. Uji disolusi menunjukkan bahwa terjadi peningkatan laju disolusi pada padatan kristal hasil rekristalisasi berbagai pelarut dibandingkan dengan karbamazepin murni.
\end{abstract}


Pada padatan kristal hasil rekristalisasi THF memiliki laju disolusi paling tinggi dari pelarut yang lain, yaitu pada menit ke-60 jumlah terdisolusi sebesar 65,09\%. Kesimpulan: Proses rekristalisasi karbamazepin dengan pelarut etanol, tetrahidrofuran dan kloroform menghasilkan polimorf baru sehingga sifat fisikokimia padatan hasil rekristalisasi berbeda dibandingkan karbamazepin murni. Berdasarkan hasil uji disolusi in vitro dapat diketahui bahwa karbamazepin hasil rekristalisasi dengan pelarut tetrahidrofuran memiliki laju disolusi yang paling tinggi.

Kata kunci: karbamazepin, rekristalisasi, pelarut, karakterisasi padatan, slow evaporation

\section{PENDAHULUAN}

Karbamazepin digunakan sebagai antikonvulsi dalam pengobatan epilepsi. Karbamazepin tergolong dalam Biopharmaceutical Classification System (BCS) kelas II yang artinya bahwa karbamazepin memiliki permeabilitas membran yang tinggi dan kelarutan dalam air yang rendah. Hal ini menjadikan proses absorpsi karbamazepin terbatas pada laju disolusi (Grzesiak dkk., 2003).

Modifikasi kristal dapat digunakan dalam upaya mengubah kelarutan dan laju disolusi obat. Salah satu cara yang paling mudah untuk memodifikasi kristal adalah dengan kristalisasi (Flicker dkk., 2012). Kristalisasi dapat mengubah karakteristik kristal seperti habit, polimorfisme dan ukuran. Sifat dan tingkat perubahan tersebut tergantung pada kondisi kristalisasi termasuk jenis pelarut dan tahap penguapan serta adanya pengotor (Yanuar dkk., 2014).

Polimorf merupakan fase padatan yang memiliki struktur internal kristal yang berbeda dengan struktur kimia sama. Fenomena polimorfisme berimplikasi bahwa satu bentuk kristal dengan bentuk kristal yang lainnya walaupun molekul sama akan berbeda sifat fisikokimia seperti kelarutan, laju disolusi, titik leleh, dan stabilitas (Partogi dkk., 2014). Pemilihan polimorf bahan baku obat yang tepat, penting dilakukan untuk keberhasilan proses produksi menjadi bentuk sediaan obat. Berbagai proses produksi sediaan farmasi seperti granulasi, pengeringan, dan pengecilan ukuran partikel dapat berdampak pada perubahan struktur kristal obat seperti amorfisasi dan polimorfisme (Indra dkk., 2019). Oleh karena itu, sejak awal penting untuk memilih bentuk polimorf obat yang unggul pada kelarutan dan stabilitas sehingga tujuan efek terapi obat tercapai dan memudahkan proses produksi sediaan (Chieng dkk., 2011).

Penelitian polimorf karbamazepin yang telah dilakukan mengungkapkan ada tiga polimorf karbamazepin yaitu bentuk I, II, dan III. Polimorf III merupakan bentuk komersial, polimorf I diperoleh dengan memanaskan polimorf III, dan bentuk II diperoleh dengan rekristalisasi pelarut etanol
(Rustichelli dkk., 2000). Namun penelitian untuk mengetahui pengaruh rekristalisasi berbagai jenis pelarut terhadap pembentukan polimorf dan evaluasi sifat fisikokimia karbamazepin belum dilakukan. Pada penelitian ini pelarut yang digunakan untuk rekristalisasi karbamazepin adalah etanol, tetrahidrofuran, dan kloroform. Padatan hasil rekristalisasi kemudian dikarakterisasi menggunakan Differential Scanning Calorimetry (DSC), Difraksi Sinar-X, dan FTIR.

\section{BAHAN DAN METODE Bahan}

Bahan yang digunakan adalah karbamazepin (PT. Indofarma), etanol EMSURE ${ }^{\circledR}$ (Merck), tetrahdrofuran EMSURE $^{\circledR}$ (THF) (Merck), kloroform EMSURE $^{\circledR}$ (Merck), aquabides (PT. Brataco).

\section{Alat}

Alat yang digunakan adalah spektrofotometer UVVis (Genesys 10S UV-Vis), magnetic stirrer (Thermo Scientific), mikroskop binokuler (XSZ-107BN), Differential Scanning Calorimeter (DSC-60A, Shimadzu), X-Ray diffraktometer (Bruker-PXRD), Fourier Transform Infrared (Drawell-520A), alat disolusi (Universal Lab, ULD-8,) timbangan analitik (Mettler Toledo AG204), desikator dan alat-alat gelas.

\section{Metode}

\section{Kristalisasi}

Sebanyak $1 \mathrm{~g}$ karbamazepin dilarutkan ke dalam masing-masing gelas kimia yang sudah berisi $25 \mathrm{~mL}$ pelarut etanol, THF dan kloroform. Masing-masing campuran kemudian diaduk menggunakan magnetic stirrer dengan kecepatan putaran 300 rpm selama 30 menit. Larutan kemudian disaring menggunakan syringe filter $0,45 \mu \mathrm{m}$ kemudian pelarut dibiarkan menguap pada suhu kamar sampai diperoleh padatan kristal.

\section{Habit kristal}

Pengamatan habit kristal dilakukan terhadap kristal karbamazepin yang telah dikristalisasi menggunakan mikroskop cahaya. Sampel yang digunakan hanya seujung spatel kemudian diamati pada mikroskop dengan mengatur lensa objektif pada perbesaran 400x. 


\section{Analisis FTIR}

Sampel baku dan hasil rekristalisasi dilakukan analisis dengan FTIR. Sampel dikempa menjadi pelet $\mathrm{KBr}$ dan direkam pada bilangan gelombang 4000 $400 \mathrm{~cm}^{-1}$.

\section{Analisis PXRD}

Penetapan pola difraksi sinar-X dilakukan menggunakan difraktometer. Sampel hasil rekristalisasi karbamazepin direkam pada sudut $2 \theta 5-45^{\circ}$ dengan step size $0,020^{\circ}$ menggunakan radiasi $\mathrm{CuK} \alpha\left(\mathrm{K}_{\alpha 1}=\right.$ $1,54060 \mathrm{~nm} ; \mathrm{K}_{\alpha 2}=1,54439 \mathrm{~nm}$ ) pada $40 \mathrm{kV}$ dan $35 \mathrm{~mA}$.

\section{Analisis DSC}

Sebanyak $50 \mathrm{mg}$ sampel diletakkan pada crucible alumina instrumen DSC. Analisis termal dilakukan pada rentang temperatur $30-20^{\circ} \mathrm{C}$ dengan laju pemanasan $10^{\circ} \mathrm{C}$ per menit dan dengan aliran gas nitrogen.

\section{Evaluasi mikromeritik}

Evaluasi mikromeritik dilakukan pada sampel karbamazepin murni dan hasil rekristalisasi. Evaluasi mikromeritik yang dilakukan terdiri dari daya alir, bobot jenis ruah, bobot jenis mampat, perbandingan Haussner, kadar pemampatan, dan indeks kompresibilitas

\section{Uji penetapan kadar}

Sebanyak $50 \mathrm{mg}$ sampel dilarutkan dengan etanol dalam labu ukur $50 \mathrm{~mL}$, kemudian diambil $2 \mathrm{~mL}$ dimasukan lagi ke dalam labu takar 50 dan tambahkan etanol sampai tanda batas. Selanjutnya serapan diukur menggunakan spektrofotometer UV-Vis pada panjang gelombang $285 \mathrm{~nm}$.

\section{Uji disolusi}

Uji disolusi menggunakan $900 \mathrm{~mL}$ air yang mengandung $1 \%$ natrium lauril sulfat dengan suhu $37^{\circ} \mathrm{C}$ $\pm 0,5^{\circ} \mathrm{C}$ dan kecepatan pengadukan $75 \mathrm{rpm}$. Karbamazepin murni dan hasil rekristalisasi diambil sebanyak $10 \mathrm{~mL}$ pada selang waktu $10,20,30,45$, dan 60 menit. Setiap pengambiilan $10 \mathrm{~mL}$ sampel diganti dengan medium disolusi pada suhu dan volume yang sama. Sampel $10 \mathrm{~mL}$ difiltrasi menggunakan syringe filter $0,45 \mu \mathrm{m}$. Pengukuran serapan sampel menggunakan spektrofotometer UV-Vis pada panjang gelombang $285 \mathrm{~nm}$ (Medina dkk., 2014).

\section{HASIL DAN PEMBAHASAN}

\section{Identifikasi bahan baku karbamazepin}

Hasil pengamatan untuk identifikasi karbamazepin dapat dilihat pada Tabel 1. Berdasarkan tabel tersebut dapat disimpulkan bahwa bahan baku yang digunakan adalah karbamazepin.
Tabel 1. Identifikasi bahan baku karbamazepin

\begin{tabular}{clll}
\hline No. & Identifikasi & Pengamatan & COA \\
\hline 1 & Bentuk & Serbuk & Sesuai \\
2 & Warna & Putih & Sesuai \\
3 & Bau & Khas & Sesuai \\
4 & Titik Leleh & $189,2^{\circ} \mathrm{C}$ & Sesuai \\
\hline
\end{tabular}

\section{Kristalisasi}

Pada proses rekristalisasi karbamazepin dilakukan dengan tiga pelarut berbeda yaitu kloroform, tetrahidrofuran, dan etanol dengan metode penguapan pelarut. Tujuan digunakan tiga pelarut yang berbeda yaitu untuk mengetahui dan mendapatkan bentuk kristal (habit) berbeda yang dapat menyebabkan terjadinya perubahan sistem kristal atau terjadi polimorfisme sehingga merubah sifat fisikokimia karbamazepin.

Padatan hasil penguapan berbagai pelarut berupa kristal berwarna putih yang selanjutnya dilakukan pengamatan habit kristal menggunakan mikroskop.

\section{Habit kristal}

Pada Gambar 1 terlihat bahwa karbamazepin murni berbentuk seperti bongkahan atau patahan kubus, hal tersebut terlihat dengan adanya bentuk persegi. Kemudian pada hasil rekristalisasi dengan pelarut kloroform, etanol dan tetrahidrofuran terlihat bahwa kristal berbentuk seperti jarum dengan ditandai adanya bentuk kristal panjang dan runcing menyerupai jarum. Perbedaan tersebut dipengaruhi oleh sifat pelarut yang digunakan dalam proses rekristalisasi.
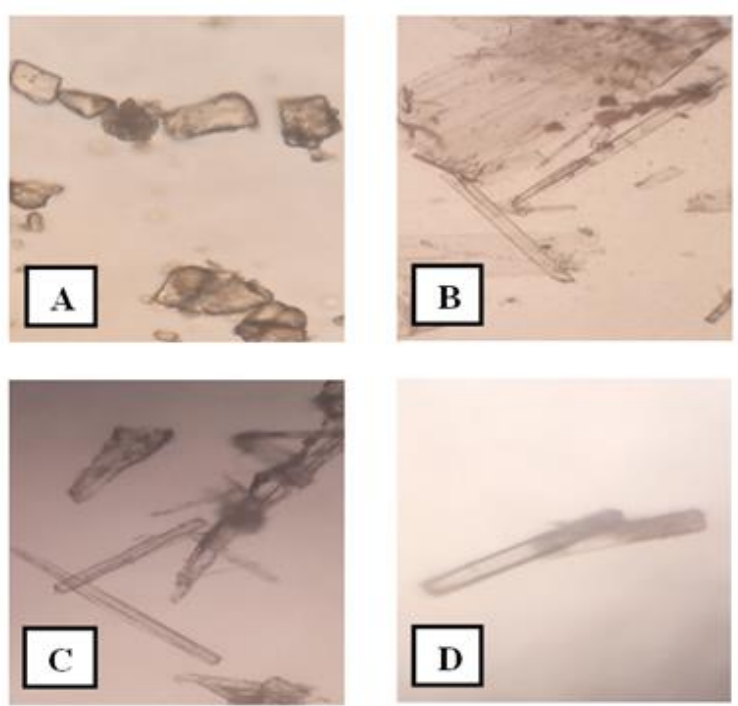

Gambar 1. Hasil mikroskopik (a) karbamazepin murni, (b) etanol, (c) kloroform, (d) THF pada perbesaran $400 \mathrm{x}$ 
Dari hasil pengamatan tersebut dapat diketahui bahwa proses rekristalisasi menyebabkan terjadinya perubahan morfologi kristal (habit) dari suatu senyawa. Secara umum perubahan habit kristal terjadi karena adanya polimorfisme pada sistem kristal, yang disebabkan karena proses rekristalisasi pada pelarut yang berbeda (Zhu dkk., 2020). Karakterisasi padatan selanjutnya dilakukan dengan menggunakan spektrofotometri FTIR, DSC dan PXRD untuk mengidentifikasi perubahan sistem kristal (polimorf).

\section{Analisis FTIR}

Analisis spektrofotometri infra merah dilakukan untuk mengetahui gugus fungsional suatu senyawa, mengidentifikasi senyawa, menentukan struktur molekul, mempelajari mekanisme reaksi (Bunaciu \& Aboul-Enein, 2020). Gambar 2 menunjukkan spektrum FTIR karbamazepin dan hasil rekristalisasi.

Bersumber pada spektrum FTIR karbamazepin murni dan hasil rekristalisasi dapat diketahui bahwa karakteristik puncak di $3464 \mathrm{~cm}^{-1}$ untuk N-H stretching, di $1674 \mathrm{~cm}^{-1}$ untuk $\mathrm{C}=\mathrm{O}$ stretching, di $1489 \mathrm{~cm}^{-1}$ untuk $\mathrm{NH}_{2}$ bonding, dan di $1384 \mathrm{~cm}^{-1}$ untuk gugus C-H. Hasil ini sesuai dengan penelitian yang telah dilakukan oleh Kristić dkk. (2015). Berdasarkan hasil pengamatan pola spektrum FTIR pada sampel serbuk hasil rekristalisasi dibandingkan dengan karbamazepin murni dapat disimpulkan bahwa proses rekristalisasi tidak merubah struktur karbamazepin.

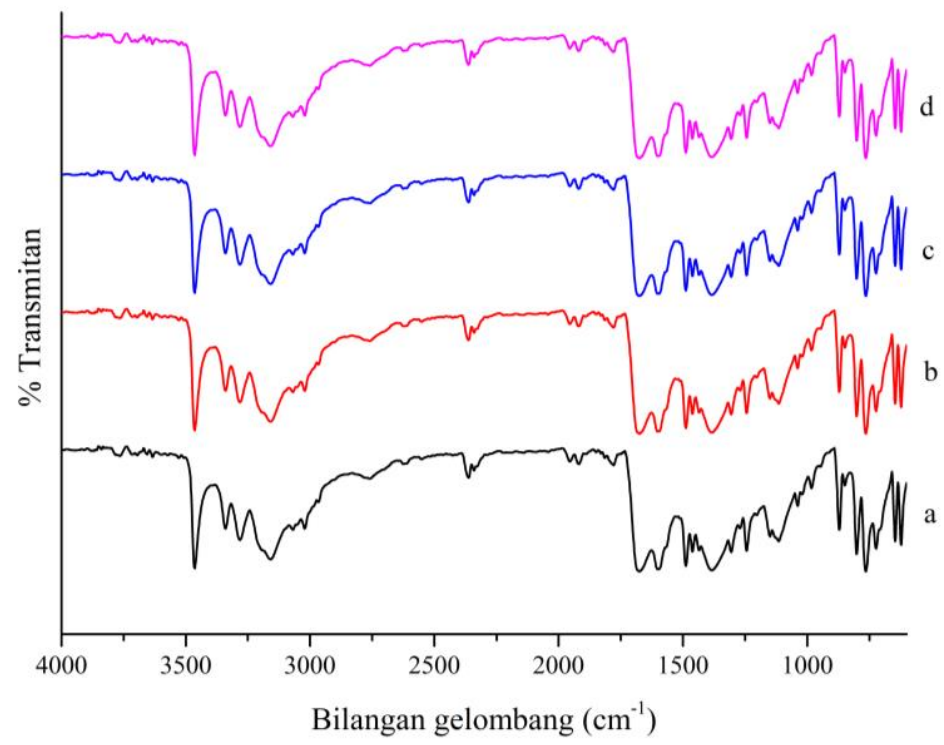

Gambar 2. Spektrum serapan FTIR (a) karbamazepin murni, (b) rekristal-etanol, (c) rekristal-THF, dan (d) rekristalkloroform

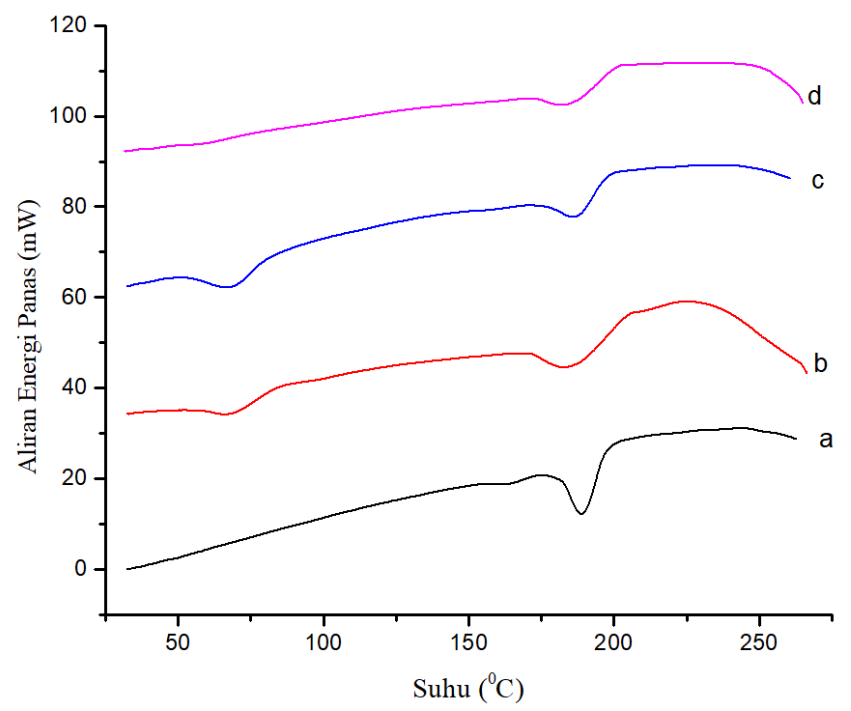

Gambar 3. Termogram DSC (a) karbamazepin murni, (b) rekristal-etanol, (c) rekristal-THF, dan (d) rekristal kloroform 


\section{Analisis DSC}

Analisis termal yang umum digunakan untuk karakterisasi padatan obat adalah Differential Scanning Calorimetry (DSC). Gambar 3 merupakan termogram DSC karbamazepin dan hasil rekristalisasi.

Bersumber pada termogram DSC diperoleh informasi bahwa pada termogram karbamazepin menunjukkan kurva transisi endotermik pada puncak $189,2^{\circ} \mathrm{C}$ dengan panas peleburan $-82,12 \mathrm{~J} / \mathrm{g}$; rekristalisasi etanol menunjukan kurva transisi endotermik pada puncak $183,3^{\circ} \mathrm{C}$ dengan panas peleburan $-42,75 \mathrm{~J} / \mathrm{g}$; rekristalisasi tetrahidrofuran menunjukan kurva transisi endotermik pada puncak $187,0^{\circ} \mathrm{C}$ dengan panas peleburan $-90,28 \mathrm{~J} / \mathrm{g}$; dan rekristalisasi kloroform menunjukan kurva transisi endotermik pada puncak $182,9^{\circ} \mathrm{C}$ dengan panas peleburan $-38,32 \mathrm{~J} / \mathrm{g}$.

Termogram analisis DSC menunjukkan bahwa telah terjadi penurunan atau peningkatan transisi endotermik dan entalpi peleburan terhadap padatan kristal hasil rekristalisasi dibandingkan dengan karbamazepin murni, hal tersebut mengindikasikan telah terjadinya perubahan bentuk polimorf karena adanya perubahan struktur internal dari kristal hasil rekristalisasi, Perubahan tersebut dipengaruhi kondisi dan pelarut yang digunakan (Abdul dkk., 2018). Analisis lebih lanjut dilakukan dengan pengamatan pola difraksi sinar-X untuk mengetahui adanya perubahan bentuk atau sistem kristal akibat pengaruh pelarut secara kristalografi.

\section{Analisis PXRD}

Uji difraksi sinar-X dilakukan untuk identifikasi perubahan sistem kristal pada sampel karbamazepin. Gambar 4 menunjukan difraktogram hasil analisis difraksi sinar-X.

Dari hasil difraktogram yang telah diketahui pola difraksi karbamazepin murni dan hasil rekristalisasi menunjukkan beberapa intensitas puncak difraksi. Pada difraktogram rekristalisasi muncul puncak-puncak yang berbeda dibandingkan karbamazepin murni yaitu pada sudut $2 \theta \quad 9,22 ; 12,36 ; 20 ;$ dan 24,45 . Hal ini mengindikasikan terbentuknya formasi fase kristal yang berbeda (polimorf) pada kristal karbamazepin hasil rekristalisasi etanol, THF dan koroform.

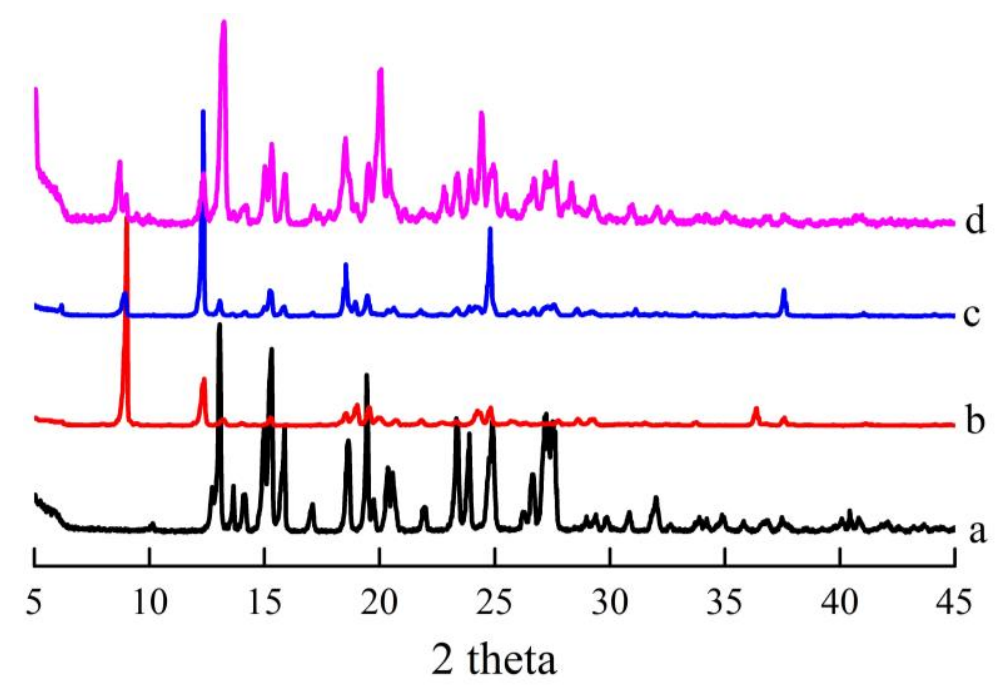

Gambar 4. Difraktogram (a) karbamazepin murni, (b) rekristal-etanol, (c) rekristal-THF, dan (d) rekristal-kloroform

Pada difraktogram hasil rekristalisasi pelarut menunjukkan intensitas difraktogram yang lebih tinggi dibandingkan dengan karbamazepin murni. Bersumber pada hasil ini maka dapat disimpulkan bahwa teknik rekristalisasi dengan pelarut dapat menyebabkan perubahan bentuk kristal (habit) dan menyebabkan terbentuknya fase kristalin baru (polimorfisme). Hal ini diperkuat dengan data termogram DSC dengan terjadinya perubahan titik leleh dan panas peleburan yang menyebabkan terjadinya perubahan internal struktur dari padatan kristal karbamazepin.

\section{Evaluasi mikromeritik}

Pengujian mikromeritik dilakukan untuk mengetahui karakter fungsional dari karbamazepin murni serta hasil dari rekristalisasi berbagai pelarut. Hasil pengujian mikromeritik dapat dilihat pada Tabel 2.

Berdasarkan data evaluasi di atas perubahan yang terjadi akibat proses rekristalisasi dengan pelarut tertentu dapat mempengaruhi tidak hanya sifat fisik kristal tetapi juga karakter fungsionalnya. Hal tersebut terlihat bahwa perubahan internal struktur dan habit kristal hasil rekristalisasi diikuti terjadinya peningkatan karakter fungsional pada padatan kristal etanol 
dibandingkan dengan karbamazepin murni serta padatan kristal THF dan kloroform.

Hasil rekristal-etanol memiliki nilai kadar pemampatan sebesar $17,5 \%$ dan kadar pemampatan memenuhi syarat jika $\leqslant 20 \%$. Indeks kompresibilitas memiliki nilai sebesar $17,49 \%$ dan serbuk memiliki aliran yang baik berada pada rentang 16 - 25\%.
Selanjutnya perbandungan Hausner memiliki nilai 1,212 dan aliran yang baik berada pada nilai < 1,25 (Maheshwari dkk., 2018). Hal tersebut menunjukkan bahwa padatan kristal hasil rekristal-etanol memiliki karakteristik mikromeritik lebih baik dibandingkan karbamazepin murni.

Tabel 2. Data pengujian mikromeritik

\begin{tabular}{ccccc}
\hline & \multicolumn{4}{c}{ Hasil Pengamatan } \\
\cline { 2 - 5 } Evaluasi Serbuk & $\begin{array}{c}\text { Karbamazepin murni } \\
(\mathrm{n}=3)\end{array}$ & $\begin{array}{c}\text { Rekristal-Etanol } \\
(\mathrm{n}=3)\end{array}$ & $\begin{array}{c}\text { Rekristal-THF } \\
(\mathrm{n}=3)\end{array}$ & $\begin{array}{c}\text { Rekristal-Kloroform } \\
(\mathrm{n}=3)\end{array}$ \\
\hline Bobot Jenis Nyata & $0,56 \mathrm{~g} / \mathrm{mL} \pm 0,552$ & $0,50 \mathrm{~g} / \mathrm{mL} \pm 0,005$ & $0,38 \mathrm{~g} / \mathrm{mL} \pm 0,002$ & $0,39 \mathrm{~g} / \mathrm{mL} \pm 0,086$ \\
Bobot Jenis Mampat & $0,71 \mathrm{~g} / \mathrm{mL} \pm 0,023$ & $0,61 \mathrm{~g} / \mathrm{mL} \pm 0,004$ & $0,50 \mathrm{~g} / \mathrm{mL} \pm 0,003$ & $0,50 \mathrm{~g} / \mathrm{mL} \pm 0,082$ \\
Haussner Ratio & $1,286 \pm 0,002$ & $1,212 \pm 0,003$ & $1,326 \pm 0,025$ & $1,298 \pm 0,035$ \\
Kadar Pemampatan & $22,20 \% \pm 0,005$ & $17,50 \% \pm 0,002$ & $24,50 \% \pm 0,002$ & $23,07 \% \pm 0,030$ \\
Indeks Kompresibilitas & $22,20 \% \pm 0,002$ & $17,49 \% \pm 0,032$ & $24,60 \% \pm 0,090$ & $23,00 \% \pm 0,004$ \\
\hline
\end{tabular}

\section{Uji penetapan kadar}

Pemeriksaan kadar karbamazepin bertujuan untuk mengetahui kandungan suatu senyawa memenuhi syarat seperti yang tertera pada masing-masing monografi.

Pada Tabel 3 dapat diketahui bahwa karbamazepin tanpa perlakuam dan hasil kristalisasi memiliki kadar sesuai dengan monografi Farmakope Indonesia edisi VI yaitu pada rentang 98\% - 102\% (Kementerian Kesehatan Republik Indonesia, 2020).

\section{Uji disolusi in vitro}

Uji disolusi ini dilakukan pada karbamazepin murni dan hasil kristalisasi dengan berbagai pelarut. Pada dasarnya disolusi diartikan sebagai proses penarikan molekul wujud padat dipermukaan oleh molekul pelarut. Secara sederhana, disolusi adalah proses perubahan wujud padat menjadi terlarut oleh pelarut yang sesuai dan jika memenuhi syarat kompendial maka diharapkan obat akan memberikan khasiat secara in-vitro dengan baik (Uddin dkk., 2011).

Tabel 3. Uji kandungan karbamazepin murni dan hasil rekristalisasi

\begin{tabular}{cc}
\hline Sampel & $\%$ Kadar \\
\hline Karbamazepin Murni & $98,67 \%$ \\
Rekristal-Etanol & $98,67 \%$ \\
Rekristal-THF & $100,79 \%$ \\
Rekristal-Kloroform & $98,93 \%$ \\
\hline
\end{tabular}

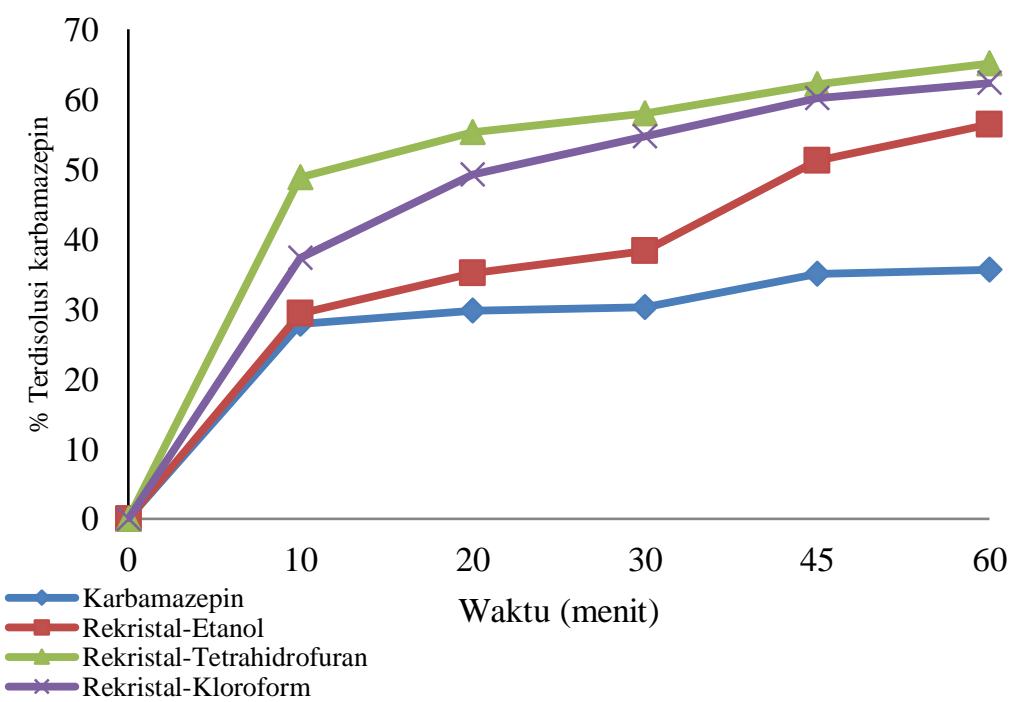

Gambar 5. Profil disolusi karbamazepin murni dan hasil kristalisasi

Berdasarkan hasil uji disolusi (Gambar 5) menunjukan perbedaan antara hasil kristalisasi berbagai pelarut dengan karbamazepin murni. Pada padatan kristal hasil kristalisasi THF memiliki laju disolusi lebih P-ISSN: 2406-9388

E-ISSN: 2580-8303 tinggi dari pada yang lain, yaitu pada menit ke-60 jumlah terdisolusi sebesar $65,09 \%$ dan terjadi peningkatan sebesar 1,83 kali dibandingkan dengan karbamazepin murni. Jumlah terdisolusi untuk 
karbamazepin murni, rekristal-etanol, rekristalkloroform masing-masing sebesar 35,60\%; 56,40\% dan $62,28 \%$. Hasil pengujian disolusi, analisis termal dan difraksi sinar-X memberikan gambaran terhadap sifat fisika dan kimia kristal hasil rekristalisasi. Pada proses rekristalisasi perbedaan pelarut yang digunakan memiliki pengaruh besar terhadap karakteristik dari padatan kristal karbamazepin yang dihasilkan. Perbedaan pelarut tersebut menunjukkan perubahan dalam bentuk pola difraktogram XRD dan termogram DSC, yang memperlihatkan terjadinya perubahan internal struktur kisi kristal karbamazepin. Perubahan ini menyebabkan perbedaan pada gaya intermolekul karbamazepin sehingga molekul pelarut pada medium disolusi lebih mudah untuk menarik molekul karbamazepin. Oleh karena itu dapat disimpulkan bahwa peningkatan laju disolusi terhadap modifikasi kristal hasil rekristalisasi berbagai pelarut dipengaruhi oleh perubahan internal struktur dari kristal karbamazepin yang diperkuat dengan data DSC dan PXRD.

\section{KESIMPULAN}

Karakterisasi padatan terhadap karbamazepin hasil rekristalisasi dengan pelarut etanol, tetrahydrofuran dan kloroform, diperoleh habit kristal yang berbeda dibandingkan karbamazepin murni. Analisis DSC dan PXRD menunjukkan bahwa terjadi pembentukan polimorf dari kristal karbamazepin murni. Berdasarkan hasil evaluasi mikromeritik dan laju disolusi dapat diketahui bahwa karbamazepin hasil rekristalisasi lebih unggul dibandingkan bentuk murni. Pelarut THF dapat menghasilkan polimorf karbamazepin dengan laju disolusi tertinggi dan dapat menjadi alternatif untuk memperbaiki laju disolusi karbamazepin. Berdasarkan penelitian ini dapat disimpulkan bahwa proses rekristalisasi dapat dimanfaatkan sebagai upaya untuk meningkatkan sifat fisikokimia karbamazepin.

\section{UCAPAN TERIMA KASIH}

Terimakasih kepada Program Studi Farmasi yang telah memfasilitasi penggunaan Laboratorium Penelitian. Peneliti juga mengucapkan terimakasih kepada Pusat Penelitian dan Pengabdian Kepada Masyarakat (P3M) Sekolah Tinggi Ilmu Kesehatan Bakti Tunas Husada yang telah mendanai penelitian ini.

\section{DAFTAR PUSTAKA}

Abdul, M. S. K., Bakar, M. R. A., Jamal, P., Adam, F., Man, R. C., Sulaiman, S. Z., Arshad, Z. I. M. \&
Shaarani, S. M. (2018). Effects of Solvents on Polymorphism and Shape of Mefenamic Acid Crystals. MATEC Web of Conferences; 150; 1-6.

Bunaciu, A. A. \& Aboul-Enein, H. Y. (2020). Adulterated Drug Analysis Using FTIR Spectroscopy. Applied Spectroscopy Reviews; 56; $1-15$.

Chieng, N., Rades, T. \& Aaltonen, J. (2011). An Overview of Recent Studies on the Analysis of Pharmaceutical Polymorphs. Journal of Pharmaceutical and Biomedical Analysis; 55; 618-644.

Kementerian Kesehatan Republik Indonesia. (2020) Farmakope Indonesia edisi VI; 824-830. Jakarta: Kementerian Kesehatan Republik Indonesia.

Flicker, F., Eberle, V. A. \& Betz, G. (2012). Recrystallization of Commercial Carbamazepine Samples - a Strategy to Control Dissolution Variability. Pharmaceutics; 4; 58-70.

Grzesiak, A. L., Lang, M., Kim, K. \& Matzger, A. J. (2003). Comparison of the Four Anhydrous Polymorphs of Carbamazepine and the Crystal Structure of Form I. Journal of Pharmaceutical Sciences; 92; 2260-2271.

Indra, I., Fauzi, A. \& Aryani, R. (2019). Karakterisasi dan Uji Disolusi Aspirin Hasil Rekristalisasi Penguapan Pelarut. Jurnal Sains Farmasi \& Klinis; 6; 164-170.

Kristić, M., Popović, M., Dobričić, V. \& Ibrić, S. (2015). Influence of Solid Drug Delivery System Formulation on Poorly Water-Soluble Drug Dissolution and Permeability. Molecules; 20; 14684-14698.

Maheshwari, R., Todke, P., Kuche, K., Raval, N. \& Tekade, R. K. (2018) Micromeritics in Pharmaceutical Product Development, Dosage Form Design Considerations: Volume I. Cambridge: Academic Press.

Medina, J. R., Salazar, D. K., Hurtado, M., Cortés, A. R. \& Domínguez-Ramírez, A. M. (2014). Comparative In Vitro Dissolution Study of Carbamazepine Immediate-Release Products Using the USP Paddles Method and the FlowThrough Cell System. Saudi Pharmaceutical Journal; 22; 141-147.

Partogi H, T., Soewandhi, S. N., Pamudji, J. S. \& Saleh, W. (2014). Preparasi dan Karakterisasi Polimorfisme Obat Anti Malaria Artesunate. Jurnal Sains Materi Indonesia; 15; 88-94. 
Rustichelli, C., Gamberini, G., Ferioli, V., Gamberini, M. C., Ficarra, R. \& Tommasini, S. (2000). Solidstate Study of Polymorphic Drugs: Carbamazepine. Journal of Pharmaceutical and Biomedical Analysis; 23; 41-54.

Uddin, R., Saffoon, N. \& Bishwajit, S. (2011). Dissolution and Dissolution Apparatus: A Review. International Journal of Current Biomedical and Pharmaceutical Research; 1; 201-207.
Yanuar, A., Nursanti, N. \& Anwar, E. (2014). Eksplorasi dan Karakterisasi berbagai Kristal Ibuprofen. Pharmaceutical Sciences and Research (PSR); 7; 43-51.

Zhu, D., Zhang, S., Cui, P., Wang, C., Dai, J., Zhou, L., Huang, Y., Hou, B., Hao, H., Zhou, L. \& Yin, Q. (2020). Solvent Effects on Catechol Crystal Habits and Aspect Ratios: A Combination of Experiments and Molecular. Crystals; 10; 1-16. 